DOI: http://doi.org/10.31617/k.knute.2019-04-12.62

Кублінська I.A., викл.

Подольська М.О., студ.

Вінницький торговельно-економічний коледж КНТЕУ,

м. Вінниця, Україна

\title{
СИСТЕМА КОНТРОЛЮ ЯКОСТІ У РЕСТОРАНІ
}

У сучасному світі інновації $є$ обов'язковою умовою розвитку та успішної конкуренції закладів ресторанного господарства. Адже сучасний споживач має високі вимоги не лише до страв та напоїв, які реалізуються в закладах ресторанного господарства, але й до якості обслуговування, чистоти, ошатності залів, зручності обслуговування тощо [1].

Важливою категорією в інноваційному розвитку закладів ресторанного господарства є раціональна система контролю та управління якістю продукції та послуг, оцінка ризиків та їх усунення, економія витрат на робочу силу та утримання закладу ресторанного господарства.

Дане завдання ефективно вирішується завдяки впровадженню в закладах ресторанного господарства системи НАССР. Система НАССР є структурованим запобіжним механізмом, завдяки якому досягається безпека споживачів та ідентифікація й контроль факторів ризику сучасного ресторану[2].

Це система покрокового контролю якості на всіх етапах виробництва та реалізації продукції та послуг. При цьому найбільша увага сконцентрована на дотриманні вимог якості у критичних контрольних точках виробництва, зберігання та реалізації харчових продуктів.

Переваги впровадження системи НАССР полягають в тому, що вона:

- зменшує ризики виготовлення та продажу харчових продуктів, тим самим гарантує споживачам високу якість продукції;

- враховує найсучасніші вимоги до якості продукції товарів та послуг та відповідає ДСТУ ISO 22000:2007 «Системи управління безпечністю харчових продуктів. Вимоги до будь-яких організацій харчового ланцюга».

Система НАССР в Україні впроваджується в сферу харчових виробництв 32016 р., однак велика кількість закладів ресторанного господарства ще до сих пір знаходяться осторонь комплексного впровадження системи НАССР та не розуміють зручності від впровадження даної системи на усіх ланках виробництва. 
Процедура впровадження НАССР включає наступні етапи:

1. Створення групи НАССР (дана група може складатися з 1-2 осіб, які мають спеціальні знання та досвід роботи у виробництві харчової продукції, управлінні та контролі якості товарів та послуг, загальних питаннях мікробіології та хімії, специфіці обслуговування споживачів та обладнання, що використовується у закладі ресторанного господарства, законодавчих нормативно-правових актів у сфері послуг).

2. Створення блок-схеми (опис стадій технологічного процесу виробництва харчової продукції, починаючи 3 моменту приймання сировини і закінчуючи утилізацією не реалізованих страв та напоїв).

3. Аналіз критичних точок (факторів ризику) з метою раціонального контролю та усунення ризиків виробництва.

4. Розробка процедури перевірок для виявлення результативності впровадження системи НАССР та корекції подальших дій.

5. Розробка документації для використання системи НАССР у конкретному закладі та проведення обліку.

Безпека харчової продукції та послуг, які надаються сучасними закладами ресторанного господарства повинна бути пріоритетною вимогою в процесі впровадження інновацій у сфері ресторанних технологій. Успішне впровадження системи НАССР забезпечить не лише правильне проведення процедур контролю якості на всіх етапах виробництва напівфабрикатів та готової продукції, а також сприятиме моніторингу всіх ризиків й недоліків, які виникають у конкретному закладі. Цим самим можливо забезпечити успішний розвиток закладу ресторанного господарства, вихід його на міжнародний рівень якості продукції та послуг, гарантувати захист сучасних споживачів.

\section{Список бібліографічних посилань}

1. «Підводні камені» ресторанного бізнесу, про які вам потрібно знати. Профі-клаб. UKR : http://www.profi-club.com.ua/uk/pidvodnikameni-restorannogo-biznesu-pro-yaki-vam-potribno-znati (Дата звернення: 08.03.2019)

2. ХАССП (НАССР) в Україні. UKR : https://lab.biz.ua/uk/ vprovadgenya-sistem-iso/hassp-upravlinnya-bezpechnistyu-produktsii/ (Дата звернення: 07.03.2019р.) 